ISBN 978-93-84422-79-0

7th International Conference on Business, Education, Law, and Sustainable Development

(BELSD-17)

Singapore Aug. 10-11, 2017

\title{
Competencies of Day Care Teacher Volunteers: Basis for a Development Program
}

\author{
Ritzcen A. Durango, PhD, Nancy R. Hernandez, PhD and Korsiney N. Cabasis, MBA \\ St. Michael's College, Philippines
}

\begin{abstract}
This study determines the competencies of day care teacher volunteers that will support pre-school kid's learning. It employs frequency and percentage distribution for the analysis of data. Validated questionnaire was used to identify their skills and capabilities in handling children. The findings revealed that many of the teacher volunteers had very high competencies in the identified areas such as however more than fifty (50\%) of them still need to be honed in the identified areas such as child care, personality development, nutritional health, literacy, numeracy and organizing creative and physical activities to be more effective and confident in their tasks. Indeed, these competencies are interrelated and shall work together to provide a complete and better picture of effective teaching practice. As a teacher of pre-schoolers, pedagogical approach, attitudes and views of knowledge which are all important aspects for preschool quality must be sustained and improved. The results of the study led to a development program that will boost the teacher volunteer's competence in dealing with preschool kids by sharing them tips in facilitating kids, strategies of teaching, preparing instructional materials for instruction, and other innovative and meaningful activities that surely will improve their capability and develop the children's competencies.
\end{abstract}

Keywords: Teacher Competencies, Day Care Teacher Volunteers, Child Care, Pre-schoolers, Development Program

\section{Introduction}

The government through Republic Act No. 6972 implements the Barangay-Level Total Development and Protection of Children. This act declares the policy of the State to defend the right of Filipino children up to six (6) years of age to assistance, including proper care and nutrition, and to provide them with special protection against all forms and other conditions prejudicial to their development. Towards this end, the various barangays through the monitoring and supervision of City Social Welfare and Development office established day care centers in every barangay with a total development and protection of children program as provided in this Act instituted in every barangay day care center. The total development and protection of children program for day care centers shall be provided for children up to six (6) years of age with the consent of parents. Adults taking charge of these classes in the (44) barangays are volunteers and not necessarily with bachelor's degree. To this end, the programs initiators undertake this research to look into the competencies of the day care teacher volunteers for the Graduate school to conceive a program which will boost the teacher volunteer's competence in dealing with preschool kids by sharing them tips in facilitating kids, strategies of teaching, preparing instructional materials for instruction, and other innovative and meaningful activities that surely will improve their capability and develop the children's competencies. 


\section{Conceptual Framework}

This study aimed at assessing the competencies of the day care teacher volunteers of the city social welfare and development office, Iligan City. Figure 1 illustrates the concept and the variable under investigation.

This research make use of the profile of the day care teacher volunteers which includes, age, sex, highest educational attainment, number of years as teacher volunteer, types of children being handled, and the financial status of trainings attended. It also includes the identification of the day care teacher volunteers' competencies based on the extent of handling and performance of the various literacy competencies and activities. Furthermore, the result of these findings will be to design a program for the graduate school community extension program.

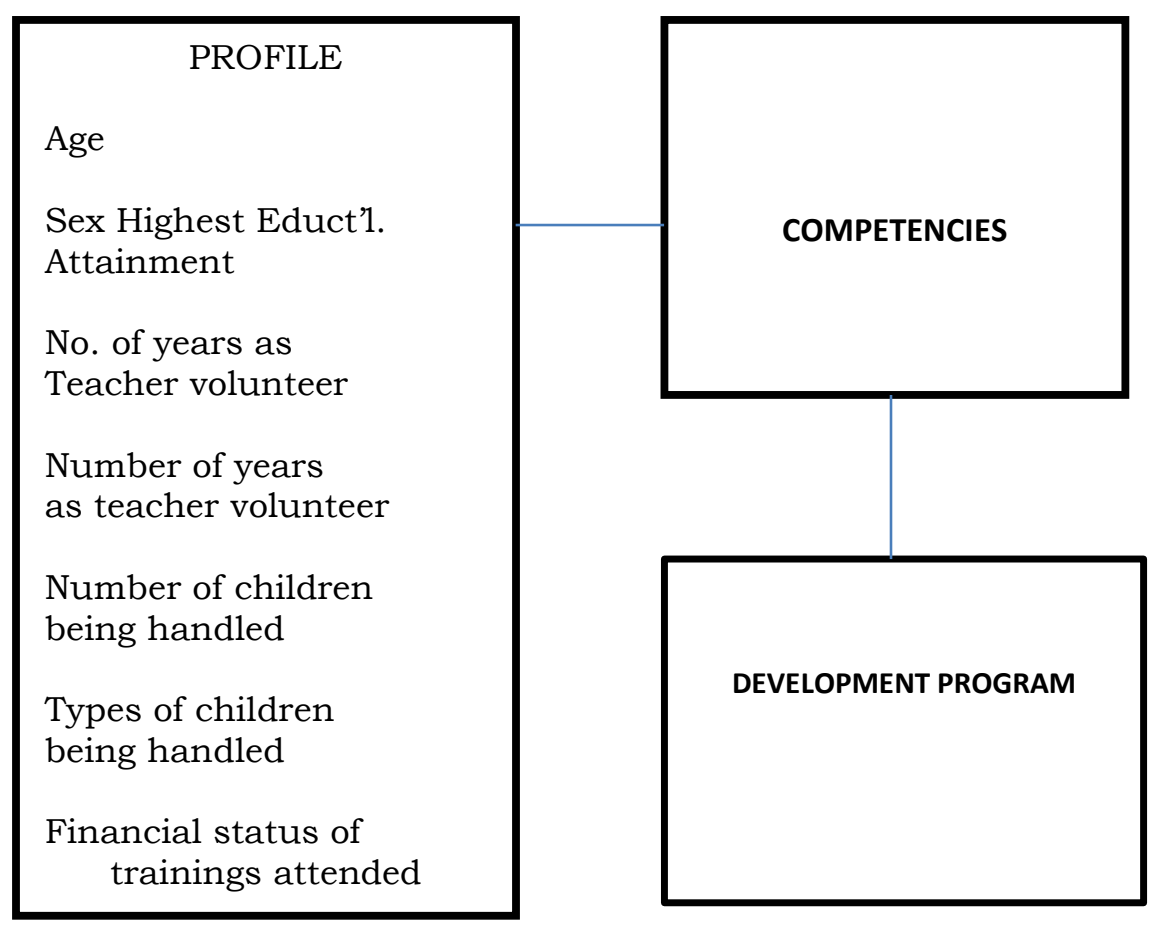

Fig.1. Research Paradigm

\section{Statement of the Problem}

The current research aimed at examining the competencies of the day care teacher volunteers of the city social welfare and development office of Iligan City. Specifically, this study sought to answer the following questions:

- What is the profile of the day care teacher volunteers in terms of:

.1 Age

.2 Sex

.3 Highest Educational Attainment

.4 No. of years as Teacher volunteer

.5 Number of children being handled

.6 Financial status of trainings attended

- What are the competencies of the day care teacher volunteers?

- What program can be designed as an output of the study? 


\section{Research Method}

This paper used a quantitative research, specifically, descriptive design and utilized only the frequency and percentage distribution for the data analysis. The day care teacher volunteers in Iligan City were purposively chosen as the respondents of the study. As revealed in the findings, most of them were female, 30 years of age and above, and at most college graduate. Data were collected through survey questionnaire which was validated by CSWD Head and experienced person who is very much aware of the needed competencies of a pre-school teacher. The questionnaire contained respondents' profile and identified activities which describe their competencies.

\section{Results and Discussions}

Table I. Distribution of Respondents' Sex

\begin{tabular}{|c|c|c|}
\hline SEX & FREQUENCY & PERCENT \\
\hline Male & 1 & .70 \\
Female & 150 & 99.30 \\
Total & $\mathbf{1 5 1}$ & $\mathbf{1 0 0 . 0 0}$ \\
\hline
\end{tabular}

Table 1 shows the distribution of the respondents' sex. As gleaned, 99.30\% are female. The findings is aligned with the research conducted by the Functional Literacy, Education and Mass Media Survey (FLEMMS), 2008 published by the Philippine Commission on Women which reveals that 89.58 percent of the public elementary school teachers are female and only 10.42 percent are male teachers. Furthermore, in the public secondary schools, 77.06 percent are female; and only 22.94 percent are male teachers.

On the other hand, According to Stahl(2010), teaching's nurturing aspects, as well as hours coinciding with those of school-age children, helped create its association with "women's work." Teaching (which is actually quite mentally, emotionally and physically taxing ) became known as an ideal job for someone who wanted to assume primary responsibility for raising a family. In addition, Gwayne (2012) stated that It is commonly assumed that women are more suited for the teaching profession as they are often considered to be more caring, compassionate and understanding of the needs of a child than male counterparts.

Table II. Distribution of Respondents' Age

\begin{tabular}{|c|c|c|}
\hline AGE & FREQUENCY & PERCENT \\
\hline 19 to 29 years old & 12 & 7.90 \\
\hline 30 to 40 years old & 41 & 27.20 \\
\hline 41 to 51 years old & 51 & 33.80 \\
\hline 52 to 62 years old & 41 & 27.20 \\
\hline 63 to 73 years old & 6 & 4.00 \\
\hline Total & $\mathbf{1 5 1}$ & $\mathbf{1 0 0 . 0 0}$ \\
\hline
\end{tabular}

Table II shows the distribution of respondents' age. As shown, 51 or $33.80 \%$ are of ages 41 to 51 and 41 or $27.20 \%$ are of ages 30-40 and 52-62 years old. It was revealed that majority of the day care teacher volunteers are in their middle adulthood (ages 40 to $65 \mathrm{yrs),} \mathrm{who} \mathrm{according} \mathrm{to} \mathrm{Erik} \mathrm{Erikson's} \mathrm{psychoanalytic} \mathrm{theory} \mathrm{of}$ psychosocial development are in the stage where they establish careers, settle down within a relationship, begin their own families and develop a sense of being a part of the bigger picture.

They give back to society through raising their children, being productive at work, and becoming involved in community activities and organizations. By failing to achieve these objectives, they become stagnant and feel 
unproductive. Success in this stage will lead to the virtue of care which was exemplified by these day care teachers' gesture of voluntary service to produce something that makes a difference to the society which is a positive element that would contribute to their effectiveness as teachers to the day care learners of the different barangays in Iligan City.

Table III. Distribution of Respondents Highest Educational Attainment

\begin{tabular}{|c|c|c|}
\hline HIGHEST EDUCATIONAL & FREQUENCY & PERCENT \\
ATTAINMENT & 1 & .7 \\
\hline High School Level & 30 & 19.9 \\
High School Graduate & 49 & 32.5 \\
College Level & 53 & 35.1 \\
College Graduate & 7 & 4.6 \\
Vocational & 11 & 7.3 \\
No Answer & $\mathbf{1 5 1}$ & $\mathbf{1 0 0 . 0}$ \\
Total & & \\
\hline
\end{tabular}

Table III shows the distribution of the respondents' highest educational attainment. As seen, 53 or $35.1 \%$ are college graduates followed by 49 or $32.5 \%$ who are in college level.

In public schools, preschool teachers are generally required to have at least a bachelor's degree in early childhood education or a related field. Bachelor's degree programs teach students about children's development, strategies to teach young children, and how to observe and document children's progress( National Association for the Education of Young Children, 2016)

It discloses that these day care teacher volunteers have adequate knowledge on the basic literacy which really needs assistance in terms of teaching pedagogy and instructional tools for teaching in the higher education department.

According to Coffman and Lopez (2003), he stated that teachers' professional preparation is a crucial component of high quality education. That's why they in direly need specialized assistance in order to possess the knowledge and skills needed to have a positive impact on students outcomes.

Table IV. Distribution of Respondents' Years in Service as Volunteer

\begin{tabular}{|c|c|c|}
\hline Years in Service as Volunteer & Frequency & Percent \\
\hline Below 1 year old & 5 & 3.3 \\
1-5 years & 28 & 18.5 \\
6-10 years & 21 & 13.9 \\
11-15 years & 24 & 15.9 \\
15-20 years & 23 & 15.2 \\
21-25 years & 13 & 8.6 \\
26 years and above & 12 & 7.9 \\
No Answer & 25 & 16.6 \\
Total & $\mathbf{1 5 1}$ & $\mathbf{1 0 0 . 0}$ \\
\hline
\end{tabular}

Table IV shows the distribution of the respondents' number of years in service as a volunteer. As observed, 81 or $53.1 \%$ have served as day care teacher volunteer from 6 years to 25 years. It discloses that these teachers have rendered sufficient number of years in their respective barangays. Their passion for service and volunteerism is magnanimous bringing them joy and dynamism as teachers in their respective barangays. This is confirmed in a study entitled “ The Health Benefits of Volunteering: A review of recent Research" conducted by the Corporation and National Community service, they have found out that those who volunteer have lower mortality rates, greater functional ability, and lower rates of depression later in life than those who do not volunteer. 
Comparisons of the health benefits of volunteering for different age groups have also shown that older volunteers are the most likely to receive greater benefits from volunteering, whether because they are more likely to face higher incidence of illness or because volunteering provides them with physical and social activity and a sense of purpose at a time when their social roles are changing.

Table V. Distribution of Respondents' Types of Children Being Handled

\begin{tabular}{|c|c|c|}
\hline TYPES OF CHILDREN BEING HANDLED & FREQUENCY & PERCENT \\
\hline Pre-schoolers & 98 & 64.9 \\
\hline Toddlers & 24 & 15.9 \\
\hline Pre-schoolers and Toddlers & 17 & 11.3 \\
\hline No Answer & 12 & 7.9 \\
\hline Total & $\mathbf{1 5 1}$ & $\mathbf{1 0 0 . 0}$ \\
\hline
\end{tabular}

Table VI presents the distribution of the respondents' types of children being handled as a volunteer day care teacher. As observed, 98 or $64.9 \%$ are handling pre-schoolers while 17 or 11.3 have a mixed class of Preschoolers and Toddlers. It discloses that these teachers have to handle literacy sessions with children having varied age bracket which shows the need for them to be acquainted and trained about various strategies of managing children in the course of the teaching -learning processes.

From the study of Coplan, Bullock, Archbell and Bosacki(2013), teachers expressed more negative views towards child aggression as compared to social withdrawal. Thus, teachers need to have trainings on how to deal with this kind of child's behavior. And most of all, how could they assist parents in preparing the child in their kindergarten. Many parents want to make sure their children are prepared, so a lot of time is spent drilling them on kindergarten learning basics such as numbers, letters, shapes, and colors(Phillips,2013).

Table VI. Respondents' Training Financial Status

\begin{tabular}{|c|c|c|}
\hline TRAINING FINANCIAL STATUS & FREQUENCY & PERCENT \\
\hline Funded & 63 & 41.7 \\
\hline Self-financed & 25 & 16.6 \\
\hline funded and self-financed & 7 & 4.6 \\
\hline None & 19 & 12.6 \\
\hline No Answer & 37 & 24.5 \\
\hline Total & $\mathbf{1 5 1}$ & $\mathbf{1 0 0 . 0}$ \\
\hline
\end{tabular}

Table VII presents the distribution of the respondents' training financial status. As gleaned, 63 or $41.7 \%$ are given free training while 25 or 16.6 percent have to shell out their own finances for their trainings. It discloses that these day care teacher volunteers have showed interest for their professional advancement be it funded or self-financed.

The table shows the respondents competencies in initiating activities mentioned above. It was evident that most of the respondents of the study have answered greatest extent with the competency on the Basic Child Care as the highest with 103 responses or 68.21 percent. The rest of the competencies are on the average with conversational English as the lowest 53 or 35.10 percent, followed by Organizing creative and physical activities and Nutritional Health, Basic Numeracy, and Personality Development.

There are still those who do not have enough awareness towards basic childcare such as guiding children's behaviour in positive, supportive, and age-appropriate ways (12.58 percentage), Basic Literacy (14.57 percentage), Basic Numeracy (16.56), Organizing creative and physical activities(17.88), Conversational English (35.09), Personality Development (16.56), and on Nutritional health (17.88).

Looking at the overall picture of the competencies of these volunteer day care teachers they still need to be honed in the identified areas to be more effective and confident in their tasks. 
Table VII. Respondents Competencies

\begin{tabular}{|c|c|c|c|c|c|c|c|c|c|c|c|c|}
\hline \multirow[t]{2}{*}{ Activities } & \multicolumn{2}{|c|}{$\begin{array}{c}\text { To a greatest } \\
\text { extent }\end{array}$} & \multicolumn{2}{|c|}{$\begin{array}{c}\text { To a greater } \\
\text { extent }\end{array}$} & \multicolumn{2}{|c|}{ Neutral } & \multicolumn{2}{|c|}{$\begin{array}{c}\text { To a } \\
\text { lesser } \\
\text { extent }\end{array}$} & \multicolumn{2}{|c|}{$\begin{array}{c}\text { To a least } \\
\text { extent }\end{array}$} & \multicolumn{2}{|c|}{ No Answer } \\
\hline & $\mathbf{f}$ & $\begin{array}{l}\text { Per } \\
\text { cent }\end{array}$ & f & $\begin{array}{c}\text { Per } \\
\text { cent }\end{array}$ & f & $\begin{array}{l}\text { Per } \\
\text { cent }\end{array}$ & $\mathbf{f}$ & $\begin{array}{l}\text { Per } \\
\text { cent }\end{array}$ & $\mathbf{f}$ & $\begin{array}{l}\text { Per } \\
\text { cent }\end{array}$ & f & $\begin{array}{l}\text { Per } \\
\text { cent }\end{array}$ \\
\hline $\begin{array}{l}\text { 1. Basic child } \\
\text { care such as } \\
\text { guiding } \\
\text { children's } \\
\text { behavior in } \\
\text { positive, } \\
\text { supportive, and } \\
\text { age-appropriate } \\
\text { ways. }\end{array}$ & 103 & 68.21 & 18 & 11.92 & 19 & 12.58 & 0 & 0.00 & 0 & 0.00 & 11 & 7.28 \\
\hline 2. Basic Literacy & 86 & 56.95 & 25 & 16.56 & 18 & 11.92 & 4 & 2.65 & 0 & 0.00 & 18 & 11.92 \\
\hline $\begin{array}{l}\text { 3. Basic } \\
\text { Numeracy }\end{array}$ & 75 & 49.67 & 32 & 21.19 & 20 & 13.25 & 5 & 3.31 & 0 & 0.00 & 19 & 12.58 \\
\hline $\begin{array}{l}\text { 4. Organizing } \\
\text { creative and } \\
\text { physical } \\
\text { activities }\end{array}$ & 74 & 49.01 & 34 & 22.52 & 26 & 17.22 & 1 & 0.66 & 0 & 0.00 & 16 & 10.60 \\
\hline $\begin{array}{l}5 . \\
\text { Conversational } \\
\text { English }\end{array}$ & 53 & 35.10 & 26 & 17.22 & 46 & 30.46 & 6 & 3.97 & 1 & 0.66 & 19 & 12.58 \\
\hline $\begin{array}{l}\text { 6. Personality } \\
\text { Development }\end{array}$ & 75 & 49.67 & 32 & 21.19 & 20 & 13.25 & 5 & 3.31 & 0 & 0.00 & 19 & 12.58 \\
\hline $\begin{array}{l}\text { 7. Nutritional } \\
\text { Health }\end{array}$ & 74 & 49.01 & 34 & 22.52 & 26 & 17.22 & 1 & 0.66 & 0 & 0.00 & 16 & 10.60 \\
\hline
\end{tabular}

\section{Summary of Findings}

- 150 or $99.30 \%$ of the respondents are female. 51 or $33.80 \%$ are of ages 41 to 51 and 41 or $27.20 \%$ of respondents' are of ages 52-62 years old.

* 53 or $35.1 \%$ of the respondents' are college graduates. 81 or $53.1 \%$ of the respondents' have 6 years to 25 years of service to the community.

* 98 or $64.9 \%$ are handling pre-schoolers while 17 or 11.3 have a mixed class of Pre-schoolers and Toddlers. 63 or $41.7 \%$ are given free training while 25 or 16.6 percent have to shell out their own finances for their trainings.

* Respondents of the study have answered greatest extent with the competency on the Basic Child Care as the highest with 103 responses or 68.21 percent. The rest of the competencies are on the average with conversational English as the lowest 53 or 35.10 percent, followed by Organizing creative and physical activities and Nutritional Health, Basic Numeracy, and Personality Development.

\section{Conclusion and Recommendations}

Teachers play a significant role in caring children especially pre-schoolers. They ensure that children are supervised at all times, and that children are involved in safe and appropriate activities. Based from the findings, many teachers have the competencies on basic child care such as guiding children's behavior in positive, supportive, and age-appropriate ways, basic Literacy, basic numeracy, organizing creative and physical activities, conversational English, personality development and nutritional health however there are still a lot who needs to hone their skills and competencies to be more effective in their tasks at hand. With their 
responsibilities to care and teach young children, they need continual trainings to further improve and enhance the way they performed in their daily tasks and sustain what is best of their competencies.

Based from the findings of the study, the following are recommended:

* That the program be implemented to respond appropriately to the needs of the children.

* That the government shall support to the implementation of the development for the growth and development of the teacher volunteers as well as to pre-schoolers.

\section{References}

[1] Copla, R.J., Bullock, A., Archbell, K.A. \& Bosacki, S. (2013, September 6). Preschool teachers' attitudes, beliefs, and emotional reactions to young children's peer group behaviors. Early Childhood Research Quarterly, $30,117-127$

[2] Corporation and National Community Service (2017). The health benefits of volunteering: A review of recent research. Retrieved February 8, 2017 from http://www.national service.gov/serve-your-community/benefits volunteering.

[3] Phillips,R. (2013). Preschoolers 101: Understanding preschooler development. Retrieved January 17, 2017 from http://www.parents.com/toddlers-preschoolers/development/behavioral/ preschoolers- 101/

[4] The Functional Literacy, Education and Mass Media Survey (2008). Published by the Philippine Commission on Women. Retrieved February 9, 2017 from http : / / www . pcw. Gov . ph / statistics / 201405 / statistics filipino - women -and-mens-education..

[5] Saul Mc Leod (2013). Simply psychology. Retrieved February 9, 2017 from http://www.simplypsychology.org Erik-Erikson.html 